Check for updates

Cite this: RSC Adv., 2019, 9, 30659

Received 20th July 2019

Accepted 12th September 2019

DOI: $10.1039 / c 9 r a 06778 g$

rsc.li/rsc-advances

\section{Transition metal-free one-pot synthesis of substituted pyrroles by employing aza-Wittig reaction $\uparrow$}

\author{
Chetna Jadala, ${ }^{a}$ Budaganaboyina Prasad, ${ }^{\text {b }}$ A. V. G. Prasanthi, ${ }^{\text {b }}$ \\ Nagula Shankaraiah (iD *a and Ahmed Kamal (iD *abc
}

A mild and metal-free one-pot synthetic strategy has been developed for the construction of substituted pyrroles by employing aza-Wittig reaction from a unique and unexplored combination of chromones and phenacyl azides. This method does not compromise the diverse substitutions on both the phenacyl azides and chromones. The merits of this method are wide substrate scope, easy functionalization, short reaction time, operationally simple, and higher yields. Moreover, this method is amenable for the generation of a library of key pyrrole building blocks.

\section{Introduction}

Pyrroles are ubiquitous and important privileged scaffolds amongst the family of five membered N-heterocyclic pharmacophores which are widely distributed in natural products, ${ }^{\mathbf{1}}$ medicinal agents ${ }^{2}$ and agrochemical research. ${ }^{3}$ Pyrroles are also having broad applications in electronics, ${ }^{4 a}$ molecular optics ${ }^{4 b}$ and widely used as versatile building blocks in organic synthesis. ${ }^{5}$ The biological activities of different substituted pyrroles such as antitumour, ${ }^{6}$ antibacterial, ${ }^{7}$ antifungal ${ }^{8}$ and immunosuppressant ${ }^{9}$ are immensely explored. A large number of pyrrole derivatives have been found to act as tubulin polymerization inhibitors, ${ }^{\mathbf{1 0}}$ pesticides, as a natural antibiotic pyoluteorin $^{11 a}$ and Cdc7 kinase inhibitor ${ }^{11 b}$ (I-III, Fig. 1). Therefore, the development of novel synthetic methods that provide substituted pyrrole derivatives is important. The traditional methods available for the synthesis of pyrroles are Paal Knorr, ${ }^{12}$ Hantzsch $^{\mathbf{1 3}}$ and Barton-Zard synthesis. ${ }^{\mathbf{1 4}}$ These classical methods not only provide insights about the advancement in developing various methods in synthesis of pyrroles but also throw light regarding the vibrant activity in this field. However these methods employ multistep operations and harsh conditions. While a plethora of outstanding synthetic methods have been developed, however, it is still challenging to achieve direct access to substituted pyrroles.

${ }^{a}$ Department of Medicinal Chemistry, National Institute of Pharmaceutical Education and Research (NIPER), Hyderabad-500 037, India. E-mail: shankar@niperhyd.ac.in ${ }^{b}$ Medicinal Chemistry \& Pharmacology, CSIR-Indian Institute of Chemical Technology, Hyderabad 500 007, India.E-mail: ahmedkamal@iict.res.in

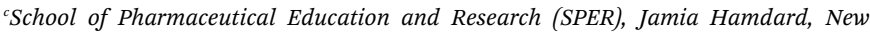
Delhi, 110062, India

$\dagger$ Electronic supplementary information (ESI) available. See DOI: 10.1039/c9ra06778g
Chromone-3-carbaldehyde is a versatile compound and widely used in the synthesis of different heterocyclic compounds. The synthesis and reactivity of the compounds have been reviewed. ${ }^{\mathbf{1 5}}$

More precisely, formyl chromones are known to demonstrate their ability to react via electron deficient centers C-2, C-4 and the formyl group. ${ }^{16}$ Beyond its reactivity, they can provide access to compounds where the chromone ring is intact or converted to 2-hydroxy benzoyl derivatives resulting from the opening of pyran-4-one ring. ${ }^{17,18}$

On the other hand, organic azides are also extensively used as amine precursors, a source of highly reactive nitrene intermediates, a valuable dipole in 1,3-dipolar cycloaddition reactions ${ }^{19}$ and as a starting material of phosphoranes employed in aza-Wittig reactions to construct a variety of heterocycles. ${ }^{20-26}$

In recent years, many reports provide inputs regarding the use of chromones in the construction of substituted pyrroles. Kamijo et al. (Scheme 1a) reported the synthesis of pyrroles with

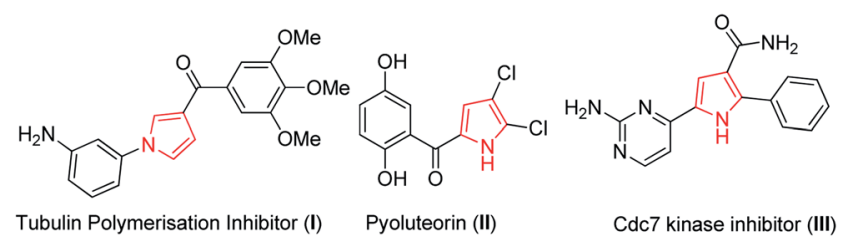

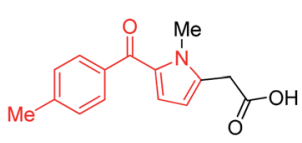

Tolmetin (IV)

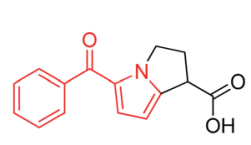

Ketorolac (V)

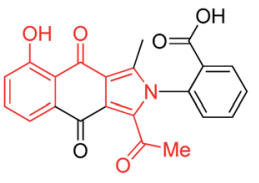

Bhimamycin D (VI)

Fig. 1 Representative examples of pyrrole based pharmaceutical derivatives. 
Kamijo et al 2005

(a)

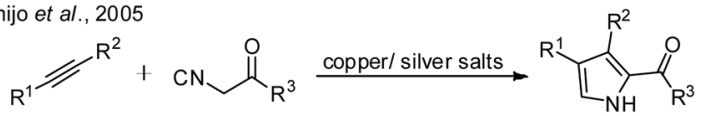

Xueyu Qi et al., 2015

(b)

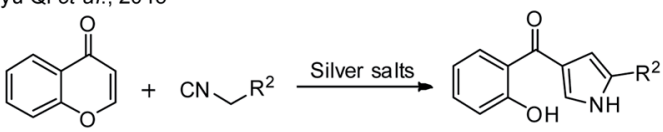

Present work

(c)

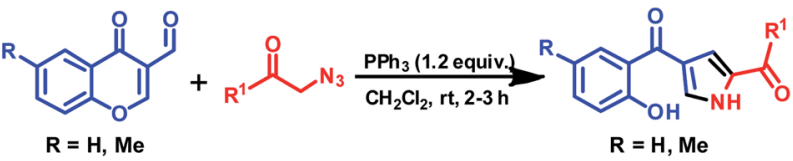

Scheme 1 Synthesis of substituted functionalized pyrroles. (a) Isocyanide and alkyne cycloaddition, (b) chromones and isocyanides and (c) the method described in the manuscript.

metal salts i.e., silver or copper salts by using isocyanides and alkynes as starting materials. ${ }^{27}$ Liao et al. ${ }^{28}$ gave insights for the synthesis of pyrrole using formyl chromones, anilines and isocyanoacetates, a three component reaction in presence of silver catalyst $\left(\mathrm{Ag}_{2} \mathrm{O}\right)$ and $\mathrm{PPh}_{3}$. The reaction proceeds via an unexpected aza-Michael addition rather than conventional imine condensation to give polysubstituted pyrroles. Later, Qi et al. (Scheme 1b) illustrated the formation of pyrrole using chromones with isocyanides in presence of silver metal salt $\left(\mathrm{Ag}_{2} \mathrm{CO}_{3}\right) .{ }^{29}$ The main drawbacks were usage of metal salt, harsh reaction conditions and multiple product formation. Hence, the efficient preparation of this class of molecules is still highly enviable. In continuation of our earlier efforts in the development of novel methods, ${ }^{30}$ herein we have reported a facile approach for synthesis of substituted pyrroles through a sequential one-pot reaction of formyl chromone and phenacyl azides (Scheme 1c). Moreover, the related highly functionalized pyrroles such as tolmetin, ketorolac (NSAIDS) and bhimamycin D (IV-VI, Fig. 1) which are the important targets in medicinal chemistry, ${ }^{\mathbf{3 1}}$ this protocol provides a rapid access to the core structure of those compounds.

\section{Results and discussion}

To develop simple and efficient route for the synthesis of pyrroles with readily available building blocks $\mathbf{1 a}$ and $\mathbf{2 a}$, the synthetic strategy began with $\mathbf{1 a}$ and $\mathbf{2 a}$ by employing dppf (entry 1 , Table 1 ) in toluene at $110{ }^{\circ} \mathrm{C}$ for $8 \mathrm{~h}$, the reaction afforded the desired product $\mathbf{4 a}$ (entry 1 , Table 1 ) in very mild $20 \%$ yield. When we used dppe, similar pattern was observed, where desired product was obtained in low yield (14\%) (entry 2, Table 1). Notably, the use of triphenylphosphine $\left(\mathrm{PPh}_{3}\right)(0.5$ and 1 equiv.) in toluene, at $110{ }^{\circ} \mathrm{C}$ for $8 \mathrm{~h}$, led to the formation of the product $4 \mathrm{a}$ albeit in lower yields i.e., $30 \%$ and $45 \%$ respectively (entry 3 and 4 Table 1). Nevertheless, to achieve higher yields, several other reaction parameters, such as reactant, solvents, reaction time and temperature were investigated (Table 1). By screening the equivalents of the reactant used in the reaction i.e., $\mathrm{PPh}_{3}$ suggested that 1.2 equiv. was considered to be
Table 1 Optimization of the reaction conditions for $4 a^{a}$

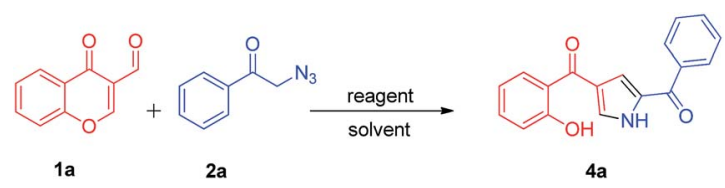

\begin{tabular}{lllllll}
\hline Entry & Reactant & Equiv. & Solvent & Temp $\left({ }^{\circ} \mathrm{C}\right)$ & Time $(\mathrm{h})$ & Yield $^{b}(\%)$ \\
\hline 1 & dppf & 0.5 & Toluene & 110 & 8 & 20 \\
2 & dppe & 0.5 & Toluene & 110 & 8 & 14 \\
3 & $\mathrm{PPh}_{3}$ & 0.5 & Toluene & 110 & 8 & 30 \\
4 & $\mathrm{PPh}_{3}$ & 1 & Toluene & 110 & 8 & 45 \\
5 & $\mathrm{PPh}_{3}$ & 1.2 & Toluene & 110 & 8 & 65 \\
6 & $\mathrm{PPh}_{3}$ & 1.2 & $\mathrm{CH}_{3} \mathrm{OH}$ & $\mathrm{rt}$ & 6 & 24 \\
7 & $\mathrm{PPh}_{3}$ & 1.2 & $\mathrm{CH}_{3} \mathrm{CN}$ & $\mathrm{rt}$ & 4 & 28 \\
8 & $\mathbf{P P h}_{3}$ & $\mathbf{1 . 2}$ & $\mathbf{C H}_{2} \mathbf{C l}$ & $\mathbf{r t}$ & 2 & $\mathbf{8 5}$ \\
9 & $\mathrm{PPh}_{3}$ & 1.2 & DMSO & $\mathrm{rt}$ & 12 & $\mathrm{n} . \mathrm{d}^{c}$ \\
10 & $\mathrm{PPh}_{3}$ & 1.2 & THF & $\mathrm{rt}$ & 4 & 28 \\
11 & $\mathrm{PPh}_{3}$ & 1.2 & Dioxane & $\mathrm{rt}$ & 12 & 15 \\
12 & $\mathrm{PPh}_{3}$ & 1.2 & DMF & $\mathrm{rt}$ & 8 & n.d
\end{tabular}

${ }^{a}$ Reactions were performed with 1a $(0.5 \mathrm{mmol})$, 2a $(0.5 \mathrm{mmol})$. ${ }^{b}$ Isolated yields. ${ }^{c}$ n.d $=$ not detected.

optimum and the desired product 4a was obtained in good yield (entry 5, Table 1). Further, to increase the yields, we have performed the reaction with different solvents such as $\mathrm{CH}_{3} \mathrm{OH}$, $\mathrm{CH}_{3} \mathrm{CN}$, DMF, $\mathrm{CH}_{2} \mathrm{Cl}_{2}$, DMSO, THF and 1,4-dioxane. When the reaction was carried out in methanol at room temperature for $6 \mathrm{~h}$, only $24 \%$ yield of the product was obtained, even though we have continued the reaction for longer time i.e., for $10 \mathrm{~h}$ (entry 6 , Table 1).

In addition, even $\mathrm{CH}_{3} \mathrm{CN}$ was inferior with regard to the yield of $4 \mathbf{a}(28 \%$, entry 7 , Table 1$)$. It was interesting to observe that when the reaction was carried out in $\mathrm{CH}_{2} \mathrm{Cl}_{2}$ at room temperature gave the desired product $4 \mathrm{a}$ in higher yield (85\%, entry 8 , Table 1). The other solvents such as THF and 1,4-dioxane gave less than $30 \%$ yield of the product (entry 10 and 11, Table 1). When DMSO and DMF were used as solvents, there was no formation of product 4a (entry 9 and 12, Table 1). Thus, use of 1.2 equiv. of $\mathrm{PPh}_{3}$ in $\mathrm{CH}_{2} \mathrm{Cl}_{2}$ (entry 8, Table 1) was found to be the optimized reaction condition for this transformation. During the course of reaction, we could identify that the reaction was proceeding via aza-Wittig mechanism by the formation of a key intermediate iminophosphorane which is responsible for the formation of substituted pyrrole. For further clarification of the product formed, we have carried out the $\mathrm{D}_{2} \mathrm{O}$ exchange (spectra can be observed in ESI $\dagger$ ) of the compound $\mathbf{4 b}$ where we could observe the trap of $\mathrm{OH}$ and $\mathrm{NH}$ proton and could confirm the formation of $\mathbf{4 b}$.

With the optimized reaction conditions in hand, substrate scope was examined by using broad range of phenacyl azides (Table 2). Taking into consideration of electronic effect by various electron rich and electron deficient substituents, we performed the reaction with different phenacyl azides having both electron donating and electron with-drawing groups. Surprisingly, both the groups were well tolerated, however 
Table 2 Synthesis of different substituted pyrroles $4 a-m$ from phenacyl azides and formyl chromone ${ }^{a}$
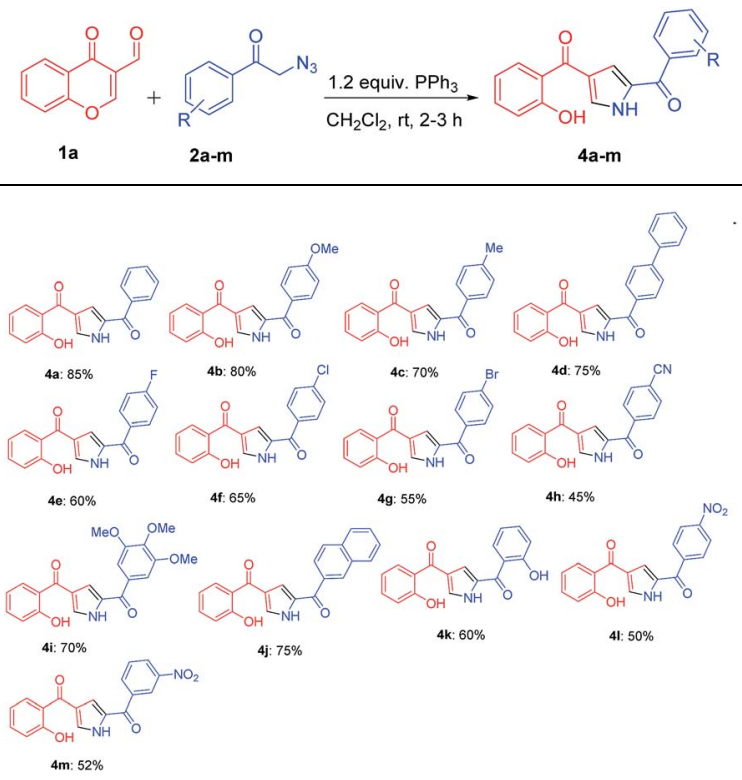

${ }^{a}$ Reactions were performed with $1 \mathrm{a}(0.5 \mathrm{mmol}), 2 \mathrm{a}(0.5 \mathrm{mmol})$ and $0.6 \mathrm{mmol}$ of $\mathrm{PPh}_{3}$ in $5 \mathrm{~mL} \mathrm{CH}_{2} \mathrm{Cl}_{2}$.

electron with-drawing groups were little inferior as compared to donating groups as in case of $4 \mathbf{a}$ and $4 \mathbf{e}$ gave 85 and $60 \%$ yields respectively. The yields were slightly decreased and required longer reaction time when phenacyl azide was substituted with 4-bromo and 4-cyano ( $4 \mathrm{~g}$ and $4 \mathbf{h}$ ) which gave 55 and $45 \%$ respectively. Notably, the methodology also exhibited compatibility of electron with-drawing substitution on ortho, para and meta of the aromatic ring and does not adversely influence the reaction outcome (4k, $4 \mathbf{l}$ and $\mathbf{4 m})$.

Further, the feasibility of this method could also be demonstrated concerning formyl chromones which were well tolerated with wide variety of phenacyl azides (Table 3). Methyl substitution on chromene ring was suitable for this reaction and was well tolerated with all electron donating and electron with-drawing groups. Moderate yields were reported with electron with-drawing substitutions such as $\mathrm{F}$ (5e, 69\%), Cl (5f, $65 \%), \mathrm{Br}(5 \mathrm{~g}, 68 \%)$ and $\mathrm{CN}(5 \mathrm{~h}, 62 \%)$. Having verified the viability of the developed protocol to obtain substituted pyrroles, we further explored the synthetic utility of this protocol by employing aliphatic azide as a substrate. To our delight, the reaction proceeded smoothly and the desired product 5n was obtained, albeit in low yield (23\%).

In order to investigate the efficiency and utility of this protocol, gram-scale reaction was carried out by employing substrates 1a (2 g, $11.4 \mathrm{mmol})$ and $2 \mathrm{~b}(2.4 \mathrm{~g}, 11.4 \mathrm{mmol})$ using TPP under optimal reaction conditions. To our delight, reaction proceeded smoothly to give the corresponding product $\mathbf{4 b}$ in $77 \%$ isolated yield (Scheme 2). This facile metal-free approach under mild conditions makes it as a useful process for the synthesis of medicinally important molecules.
Table 3 Scope of phenacyl azides with 6-methyl formyl chromone ${ }^{a}$
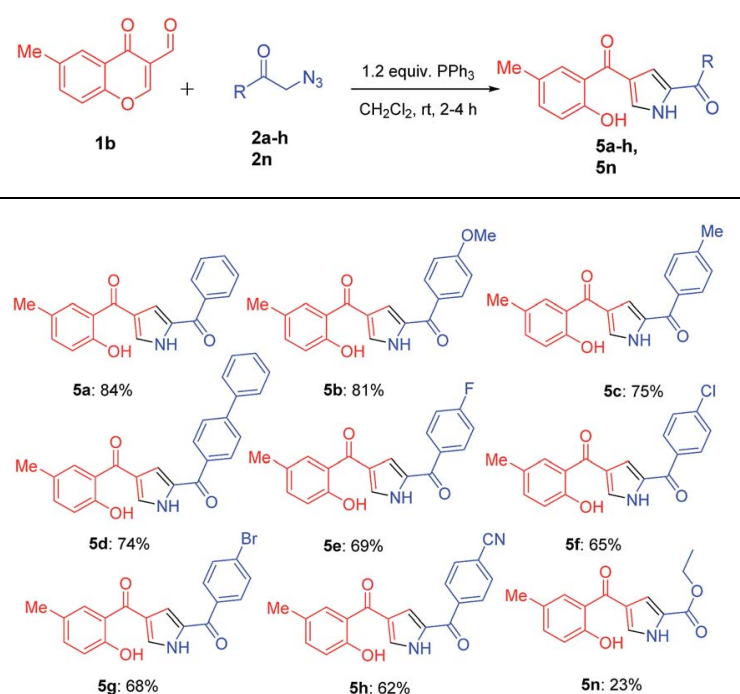

${ }^{a}$ Reactions were performed with 1a $(0.5 \mathrm{mmol}), 2 \mathrm{a}(0.5 \mathrm{mmol})$ and $0.6 \mathrm{mmol}$ of $\mathrm{PPh}_{3}$ in $5 \mathrm{~mL} \mathrm{CH} \mathrm{Cl}_{2}$.

To shed some light on the transformation of the reaction, a model reaction was performed with $\mathbf{2 b}$ and $\mathrm{PPh}_{3}$ which was monitored for the formation of (i) with the help of NMR. From NMR we could speculate that the appearance of protons in the region 4.0-4.5 ppm are of ylide protons in spectra (B) after $1.5 \mathrm{~h}$ of reaction time indicates the formation of (i). Later 1a was added and scanned for NMR we could detect an aldehydic proton at around $10.5 \mathrm{ppm}$, after $1.5 \mathrm{~h}$ of reaction time the aldehydic proton was diminishing indicating the formation of pyrrole ring by the observation of $\mathrm{NH}$ proton peak at $12 \mathrm{ppm}$ (spectra (C)) and similarly $\mathrm{OH}$ proton peak at $11 \mathrm{ppm}$ was observed with concomitant decrease in the intensity of active methylene proton of chromone (comparative NMR spectra can be viewed from ESI $\dagger$ ).

Based on the above observation and prior available literature reports $^{32}$ a plausible mechanistic pathway for the formation of pyrroles is outlined in scheme 3 . The reaction proceeds via formation of a key intermediate $N$-(triphenylphosphoranylidene) benzamide (i), the iminophosphorane through nucleophilic addition of the aryl phosphine at the terminal nitrogen atom of the phenacyl azide with expulsion of nitrogen. The nucleophilic nitrogen of iminophosphorane $\mathbf{i}$ further attacks the electrophilic carbon of aldehydic group of chromone 1a forming the carbon-nitrogen double bond of an imine ii

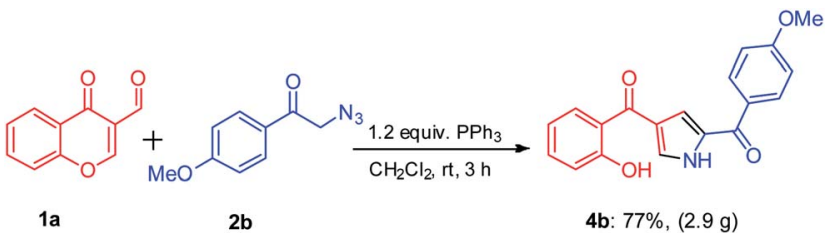

Scheme 2 Gram scale synthesis of $4 \mathrm{~b}$. 

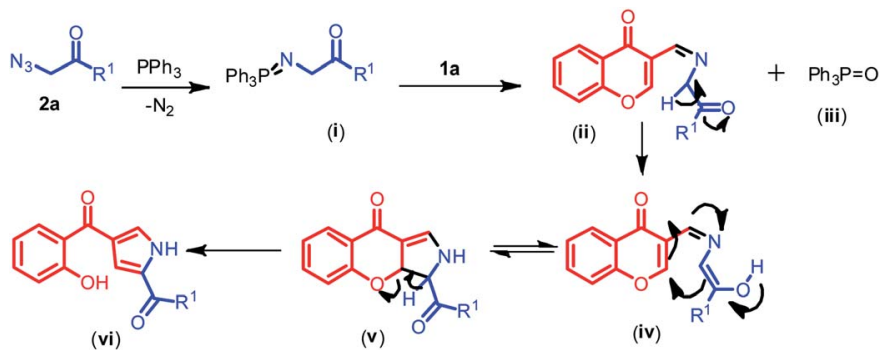

(iv)

Scheme 3 Plausible reaction pathway

along with the formation of byproduct phosphine oxide (iii), later an enolate (iv) is generated from ii through keto-enol tautomerisation which then readily cyclises resulting in the formation of dihydrochromeno pyrrole (v). Later, the keto intermediate $\mathbf{v}$ may readily aromatize and then followed by subsequent pyran ring opening and formation of pyrrole ring vi was observed.

\section{Conclusion}

In conclusion, we have developed an operationally simple onepot strategy for the synthesis of substituted pyrroles in metalfree conditions. Both electron with-drawing and electron donating groups on phenacyl azides were well tolerated including with chromones. Metal-free, mild reaction conditions and short reaction time is the exclusive feature of this approach. Moreover, the gram scale synthesis was accomplished and this protocol may possibly find applications in the natural product synthesis and drug discovery. The reactions were performed under an ambient atmosphere with no need for the exclusion of moisture or air. In addition, it is an environmentally friendly procedure as triphenyl phosphine oxide is the only byproduct generated during the reaction. Further applications of this approach in synthesis of various natural and pharmaceutically important heterocyclic compounds are ongoing in our laboratory.

\section{Experimental section}

\section{General information}

Unless otherwise specified, all solvents and other reagents are commercially available and used without further purification. All reagents were weighed and handled in air at room temperature. Column chromatography was performed on silica gel (60-120 and 100-200 mesh). NMR spectra were recorded on Bruker 500 NMR spectrometer. Chemical shifts were mentioned in parts per million $(\mathrm{ppm}, \delta)$. Proton coupling patterns are described as singlet (s), doublet (d), triplet $(\mathrm{t})$, quartet (q), doublet of doublet (dd), doublet triplet (dt) and multipet (m). HRMS were determined in negative mode with Agilent QTOF mass spectrometer 6540 series instrument. Melting points are determined on an electro thermal melting point apparatus and are uncorrected. The names of all compounds given in the Experimental section were taken from Chem ultra, version 12.0. The reactions wherever anhydrous conditions required are carried under nitrogen positive pressure using freshly distilled solvents. All evaporation of solvents was carried out under reduced pressure on Heidolph rotary evaporator below 40$45{ }^{\circ} \mathrm{C}$.

General procedure for synthesis of substituted pyrroles: (4am), (5a-5h, 5n)

A mixture of phenacyl azide and $\mathrm{CH}_{2} \mathrm{Cl}_{2}$ was taken in a $10 \mathrm{~mL}$ round bottomed flask and stirred for $5 \mathrm{~min}$; later $\mathrm{PPh}_{3}$ was added and further stirred for $30 \mathrm{~min}$. Then the chromone was added and left at rt until the completion of reaction. After confirmed by TLC, the reaction mixture was quenched with water and extracted with $\mathrm{CH}_{2} \mathrm{Cl}_{2}(25 \mathrm{~mL} \times 2)$, washed with brine $(10 \mathrm{~mL})$ and dried over anhydrous $\mathrm{Na}_{2} \mathrm{SO}_{4}$, filtered and concentrated in vacuo to give the crude product, which was further purified by silica gel chromatography using an ethyl acetate/petroleum ether gradient mixture to afford the desired product (4a-4m), (5a-5h, $5 \mathbf{n})$.

(5-Benzoyl-1H-pyrrol-3-yl)(2-hydroxyphenyl) methanone (4a). As a off white solid, yield $85 \%, \mathrm{mp} 138-140{ }^{\circ} \mathrm{C} ;{ }^{1} \mathrm{H}$ NMR (500 $\mathrm{MHz}, \mathrm{CDCl}_{3}$ ): $\delta 11.97$ (s, 1H), $10.29(\mathrm{~s}, 1 \mathrm{H}), 7.98-7.93(\mathrm{~m}, 2 \mathrm{H})$, $7.87(\mathrm{dd}, J=8.0,1.6 \mathrm{~Hz}, 1 \mathrm{H}), 7.75(\mathrm{dd}, J=3.2,1.3 \mathrm{~Hz}, 1 \mathrm{H}), 7.66-$ $7.60(\mathrm{~m}, 1 \mathrm{H}), 7.56-7.47(\mathrm{~m}, 3 \mathrm{H}), 7.38(\mathrm{dd}, J=2.4,1.4 \mathrm{~Hz}, 1 \mathrm{H})$, $7.06(\mathrm{dd}, J=8.4,0.9 \mathrm{~Hz}, 1 \mathrm{H}), 6.96-6.91(\mathrm{~m}, 1 \mathrm{H}) ;{ }^{13} \mathrm{C}$ NMR $(125$ $\left.\mathrm{MHz}, \mathrm{CDCl}_{3}\right): \delta$ 193.6, 185.3, 162.6, 137.3, 135.7, 132.7, 131.7, 131.5, 129.4, 129.1, 128.7, 125.5, 120.1, 119.8, 118.9, 118.5; HRMS (ESI): $m / z$ cald for $\mathrm{C}_{18} \mathrm{H}_{13} \mathrm{NO}_{3}[\mathrm{M}-\mathrm{H}]^{-\cdot} 290.0823$ found 290.0824 .

(4-(2-Hydroxybenzoyl)-1H-pyrrol-2-yl)(4-methoxyphenyl) methanone (4b). As a yellow solid, yield, $80 \%$, mp $125-127{ }^{\circ} \mathrm{C}$; ${ }^{1} \mathrm{H}$ NMR $\left(500 \mathrm{MHz}, \mathrm{CDCl}_{3}\right): \delta 11.99(\mathrm{~s}, 1 \mathrm{H}), 10.32(\mathrm{~s}, 1 \mathrm{H}), 8.02-$ $7.96(\mathrm{~m}, 2 \mathrm{H}), 7.88(\mathrm{dd}, J=8.0,1.5 \mathrm{~Hz}, 1 \mathrm{H}), 7.72(\mathrm{dd}, J=3.2$, $1.3 \mathrm{~Hz}, 1 \mathrm{H}), 7.52-7.47(\mathrm{~m}, 1 \mathrm{H}), 7.38(\mathrm{dd}, J=2.3,1.5 \mathrm{~Hz}, 1 \mathrm{H}), 7.06$ $(\mathrm{d}, J=7.9 \mathrm{~Hz}, 1 \mathrm{H}), 7.01(\mathrm{dd}, J=9.2,2.3 \mathrm{~Hz}, 2 \mathrm{H}), 6.94(\mathrm{dd}, J=$ 11.1, $4.0 \mathrm{~Hz}, 1 \mathrm{H}), 3.91(\mathrm{~s}, 3 \mathrm{H}) ;{ }^{13} \mathrm{C}$ NMR $\left(125 \mathrm{MHz}, \mathrm{CDCl}_{3}\right)$ : $\delta$ 193.7, 184.0, 163.5, 162.5, 135.6, 131.8, 131.6, 131.5, 129.8, 129.2, 125.3, 120.2, 119.1, 118.9, 118.4, 114.0, 55.5; HRMS (ESI): $m / z$ cald for $\mathrm{C}_{19} \mathrm{H}_{15} \mathrm{NO}_{4}[\mathrm{M}-\mathrm{H}]^{-\cdot} 320.0928$ found 320.0931 .

(4-(2-Hydroxybenzoyl)-1 H-pyrrol-2-yl)(p-tolyl)methanone

(4c). As a light yellow solid, yield $70 \%$, mp $154-156{ }^{\circ} \mathrm{C} ;{ }^{1} \mathrm{H}$ NMR $\left(500 \mathrm{MHz}, \mathrm{CDCl}_{3}\right): \delta 11.98(\mathrm{~s}, 1 \mathrm{H}), 10.36(\mathrm{~d}, J=40.7 \mathrm{~Hz}, 1 \mathrm{H})$, $7.90-7.86(\mathrm{~m}, 3 \mathrm{H}), 7.74(\mathrm{dd}, J=3.2,1.4 \mathrm{~Hz}, 1 \mathrm{H}), 7.50(\mathrm{ddd}, J=$ 8.6, 7.3, 1.6 Hz, 1H), $7.38(\mathrm{dd}, J=2.4,1.4 \mathrm{~Hz}, 1 \mathrm{H}), 7.33(\mathrm{~d}, J=$ $7.9 \mathrm{~Hz}, 2 \mathrm{H}), 7.08-7.04(\mathrm{~m}, 1 \mathrm{H}), 6.95-6.91(\mathrm{~m}, 1 \mathrm{H}), 2.46(\mathrm{~s}, 3 \mathrm{H})$; ${ }^{13} \mathrm{C}$ NMR (125 MHz, $\left.\mathrm{CDCl}_{3}\right): \delta$ 193.6, 185.1, 162.6, 143.6, 135.6, 134.6, 131.9, 131.6, 129.4, 129.4, 129.3, 125.4, 120.2, 119.6, 118.9, 118.4, 21.7; HRMS (ESI): $m / z$ cald for $\mathrm{C}_{19} \mathrm{H}_{15} \mathrm{NO}_{3}$ [M $\mathrm{H}]^{-\cdot} 304.0979$ found 304.0982 .

(5-([1,1'-Biphenyl]-4-carbonyl)-1H-pyrrol-3-yl)(2-

hydroxyphenyl)methanone (4d). As a cream solid 75\%, mp 188$190{ }^{\circ} \mathrm{C} ;{ }^{1} \mathrm{H}$ NMR $\left(500 \mathrm{MHz}, \mathrm{CDCl}_{3}\right): \delta 11.97(\mathrm{~s}, 1 \mathrm{H}), 10.15(\mathrm{~s}, 1 \mathrm{H})$, 8.07-8.03 (m, 2H), $7.89(\mathrm{dd}, J=8.0,1.6 \mathrm{~Hz}, 1 \mathrm{H}), 7.77-7.74(\mathrm{~m}$, $3 \mathrm{H}), 7.67-7.64(\mathrm{~m}, 2 \mathrm{H}), 7.52-7.47(\mathrm{~m}, 3 \mathrm{H}), 7.45-7.40(\mathrm{~m}, 2 \mathrm{H})$, 7.07 (dd, $J=8.4,1.0 \mathrm{~Hz}, 1 \mathrm{H}), 6.94(\mathrm{ddd}, J=8.2,7.3,1.1 \mathrm{~Hz}$, 1H) $\mathrm{ppm} ;{ }^{13} \mathrm{C}$ NMR $\left(125 \mathrm{MHz}, \mathrm{CDCl}_{3}\right): \delta$ 193.6, 184.6, 162.6, $145.7,139.8,135.8,135.7,131.8,131.6,129.7,129.2$, 129.0, 
128.3, 127.4, 127.3, 125.6, 120.2, 119.4, 118.9, 118.5; HRMS (ESI): $m / z$ cald for $\mathrm{C}_{24} \mathrm{H}_{17} \mathrm{NO}_{3}[\mathrm{M}-\mathrm{H}]^{-\cdot} 366.1136$ found 366.1140 .

(5-(4-Fluorobenzoyl)-1H-pyrrol-3-yl)(2-hydroxyphenyl) methanone (4e). As a pale yellow solid, yield 60\%, mp 162$165{ }^{\circ} \mathrm{C} ;{ }^{1} \mathrm{H}$ NMR (500 MHz, DMSO-d $\left.)_{6}\right): \delta 12.83(\mathrm{~s}, 1 \mathrm{H}), 10.92(\mathrm{~s}$, $1 \mathrm{H}), 7.97(\mathrm{dd}, J=10.2,3.8 \mathrm{~Hz}, 2 \mathrm{H}), 7.73(\mathrm{~s}, 1 \mathrm{H}), 7.63(\mathrm{~d}, J=$ $7.7 \mathrm{~Hz}, 1 \mathrm{H}), 7.49-7.37$ (m, 3H), 7.15 (s, 1H), 7.02-6.92 (m, 2H); ${ }^{13} \mathrm{C}$ NMR (125 MHz, DMSO-d $\left.{ }_{6}\right) \delta 191.9,183.6,165.8,163.9$, 158.2, 134.4, 134.1, 131.8, 131.1, 131.6, 131.9, 130.8, 125.6, 124.7, 119.1, 119.7, 117.1, 116.1, 116.3; HRMS (ESI): $\mathrm{m} / \mathrm{z}$ cald for $\mathrm{C}_{18} \mathrm{H}_{12} \mathrm{FNO}_{3}[\mathrm{M}-\mathrm{H}]^{-\cdot} 308.0728$ found 308.0735.

(5-(4-Chlorobenzoyl)-1H-pyrrol-3-yl)(2-hydroxyphenyl) methanone (4f). As a light yellow solid, yield $65 \%$, mp $185-187{ }^{\circ} \mathrm{C} ;{ }^{1} \mathrm{H}$ $\operatorname{NMR}\left(500 \mathrm{MHz} \mathrm{CDCl}_{3}\right): \delta 11.94(\mathrm{~s}, 1 \mathrm{H}), 10.32(\mathrm{~s}, 1 \mathrm{H}), 7.91(\mathrm{~d}, J=$ $8.4 \mathrm{~Hz}, 2 \mathrm{H}), 7.85$ (dd, $J=7.9,1.2 \mathrm{~Hz}, 1 \mathrm{H}), 7.76(\mathrm{~d}, J=1.9 \mathrm{~Hz}$, $1 \mathrm{H}), 7.50(\mathrm{t}, J=7.0 \mathrm{~Hz}, 2 \mathrm{H}), 7.36(\mathrm{~s}, 1 \mathrm{H}), 7.07(\mathrm{~d}, J=8.2 \mathrm{~Hz}, 1 \mathrm{H})$, $6.93(\mathrm{t}, J=7.5 \mathrm{~Hz}, 1 \mathrm{H}) ;{ }^{13} \mathrm{C}$ NMR $\left(125 \mathrm{MHz}, \mathrm{CDCl}_{3}\right): \delta$ 193.5, $183.8,162.6$, 139.3, 135.8, 135.5, 131.5, 131.4, 130.6, 130.4, 129.2, 129.2, 129.0, 125.7, 120.1, 119.6, 118.9, 118.5; HRMS (ESI): $m / z$ cald for $\mathrm{C}_{18} \mathrm{H}_{12} \mathrm{ClNO}_{3}[\mathrm{M}-\mathrm{H}]^{-\cdot} 324.0433$ found 324.0409 .

\section{(5-(4-Bromobenzoyl)-1H-pyrrol-3-yl)(2-hydroxyphenyl)} methanone (4g). As a light brown solid, yield 55\%, mp 178$180{ }^{\circ} \mathrm{C} ;{ }^{1} \mathrm{H}$ NMR (500 MHz, DMSO-d $\left.)_{6}\right): \delta 12.84(\mathrm{~s}, 1 \mathrm{H}), 10.90(\mathrm{~s}$, 1H), 7.86-7.75 (m, 4H), 7.71 (dd, $J=12.5,5.3 \mathrm{~Hz}, 1 \mathrm{H}), 7.62$ (d, $J$ $=7.2 \mathrm{~Hz}, 1 \mathrm{H}), 7.44(\mathrm{t}, J=7.2 \mathrm{~Hz}, 1 \mathrm{H}), 7.15(\mathrm{~s}, 1 \mathrm{H}), 7.01-6.91(\mathrm{~m}$, $2 \mathrm{H}) ;{ }^{13} \mathrm{C}$ NMR (125 MHz, DMSO-d 6 ): $\delta 191.8,183.8,158.5,137.0$, $134.1,132.3,132.1,132.0,131.7,131.5,131.1,130.8,126.6$, 126.2, 125.8, 124.3, 119.9, 119.6, 117.5; HRMS (ESI): $\mathrm{m} / \mathrm{z}$ cald for $\mathrm{C}_{18} \mathrm{H}_{12} \mathrm{BrNO}_{3}[\mathrm{M}-2 \mathrm{H}]^{-\cdot} 367.9928$ found 367.9929 .

4-(4-(2-Hydroxybenzoyl)-1H-pyrrole-2-carbonyl)benzonitrile (4h). As a pale yellow solid, yield $45 \%, \mathrm{mp} 208-210{ }^{\circ} \mathrm{C} ;{ }^{1} \mathrm{H}$ NMR (500 MHz, DMSO-d $\left.{ }_{6}\right): \delta 12.94(\mathrm{~s}, 1 \mathrm{H}), 10.89(\mathrm{~s}, 1 \mathrm{H}), 8.03(\mathrm{dt}, J=$ 16.3, $5.5 \mathrm{~Hz}, 4 \mathrm{H}), 7.77(\mathrm{~d}, J=2.0 \mathrm{~Hz}, 1 \mathrm{H}), 7.61(\mathrm{~d}, J=7.6 \mathrm{~Hz}, 1 \mathrm{H})$, $7.45(\mathrm{t}, J=7.7 \mathrm{~Hz}, 1 \mathrm{H}), 7.14(\mathrm{~s}, 1 \mathrm{H}), 7.00-6.92(\mathrm{~m}, 2 \mathrm{H}) ;{ }^{13} \mathrm{C} \mathrm{NMR}$ (125 MHz, DMSO-d ${ }_{6}$ ): $\delta$ 191.7, 185.2, 183.6, 168.8, 158.6, 141.8, $134.4,134.1,133.5,133.1,132.4,131.4,131.0,130.2,129.7$, 126.2 , 126.0, 124.5, 124.3, 120.6, 119.6, 118.6, 117.6, 114.8, 104.0; HRMS (ESI): $m / z$ cald for $\mathrm{C}_{19} \mathrm{H}_{12} \mathrm{~N}_{2} \mathrm{O}_{3}[\mathrm{M}-\mathrm{H}]^{-\cdot} 315.0775$ found 315.0779 .

(4-(2-Hydroxybenzoyl)-1H-pyrrol-2-yl)(3,4,5 trimethoxyphenyl)methanone (4i). As a light yellow solid, yield 70\%, $\mathrm{mp}$ 203-205 ${ }^{\circ} \mathrm{C} ;{ }^{1} \mathrm{H}$ NMR $\left(500 \mathrm{MHz}, \mathrm{CDCl}_{3}\right): \delta 11.96(\mathrm{~s}, 1 \mathrm{H}), 10.08$ (s, $1 \mathrm{H}), 7.88(\mathrm{dd}, J=7.9,1.2 \mathrm{~Hz}, 1 \mathrm{H}), 7.74(\mathrm{~d}, J=1.7 \mathrm{~Hz}, 1 \mathrm{H}), 7.53-$ $7.48(\mathrm{~m}, 1 \mathrm{H}), 7.38(\mathrm{~s}, 1 \mathrm{H}), 7.26(\mathrm{~s}, 1 \mathrm{H}), 7.07$ (d, $J=8.1 \mathrm{~Hz}, 1 \mathrm{H})$, $6.92(\mathrm{t}, J=7.3 \mathrm{~Hz}, 1 \mathrm{H}), 3.92(\mathrm{dd}, J=32.3,12.9 \mathrm{~Hz}, 9 \mathrm{H}) ;{ }^{13} \mathrm{C} \mathrm{NMR}$ $\left(125 \mathrm{MHz}, \mathrm{CDCl}_{3}\right): \delta$ 193.6, 184.0, 162.6, 153.2, 155.0, 142.5, $135.8,134.3,132.2$, 131.6, 131.5, 129.0, 126.4, 125.7, 125.5, 120.1, 119.0, 118.8, 118.5, 108.3, 106.7, 61.0, 56.4, 56.3; HRMS (ESI): $m / z$ cald for $\mathrm{C}_{21} \mathrm{H}_{19} \mathrm{NO}_{6}[\mathrm{M}-\mathrm{H}]^{-} 380.1140$ found 380.1142 .

(5-(2-Naphthoyl)-1H-pyrrol-3-yl)(2-hydroxyphenyl)

methanone (4j). As a cream solid, yield 75\%, mp 194-196 ${ }^{\circ} \mathrm{C} ;{ }^{1} \mathrm{H}$ NMR (500 MHz, DMSO-d $\left.{ }_{6}\right): \delta 12.89(\mathrm{~s}, 1 \mathrm{H}), 10.96(\mathrm{~s}, 1 \mathrm{H}), 8.56(\mathrm{~s}$, 1H), 8.24-7.91 (m, 4H), $7.72(\mathrm{~d}, J=46.2 \mathrm{~Hz}, 4 \mathrm{H}), 7.45(\mathrm{~s}, 1 \mathrm{H})$, 7.26 (s, 1H), 7.03-6.93 (m, 2H); ${ }^{13} \mathrm{C}$ NMR (125 MHz, DMSO-d 6 ): $\delta 191.9,184.8,158.6,135.3,135.1,134.1,132.5,131.9,131.7$, $131.0,130.3,129.9,128.8,128.8,128.2,127.5,125.7,125.4$, 124.4, 119.9, 119.6, 117.6; HRMS (ESI): $m / z$ cald for $\mathrm{C}_{22} \mathrm{H}_{15} \mathrm{NO}_{3}$ $[\mathrm{M}-\mathrm{H}]^{-\bullet} 340.0979$ found 340.0983 .

(1H-Pyrrole-2,4-diyl)bis((2-hydroxyphenyl)methanone) (4k). As a brown solid, yield $60 \%, \mathrm{mp} 175-178{ }^{\circ} \mathrm{C} ;{ }^{1} \mathrm{H}$ NMR $(500 \mathrm{MHz}$, DMSO-d $\left.\mathrm{d}_{6}\right): \delta 12.76(\mathrm{~s}, 1 \mathrm{H}), 10.89(\mathrm{~s}, 1 \mathrm{H}), 10.43(\mathrm{~s}, 1 \mathrm{H}), 7.68(\mathrm{~s}$, $1 \mathrm{H}), 7.58(\mathrm{dd}, J=18.0,7.6 \mathrm{~Hz}, 2 \mathrm{H}), 7.43(\mathrm{~s}, 2 \mathrm{H}), 7.03(\mathrm{~s}, 1 \mathrm{H}), 6.96$ (dt, $J=12.6,7.4 \mathrm{~Hz}, 4 \mathrm{H}) \mathrm{ppm} ;{ }^{13} \mathrm{C}$ NMR (125 MHz, DMSO-d 6 ): $\delta 191.8,186.1,158.5,157.4,134.0,133.5,132.5,131.5,130.8$, 130.3, 125.6, 124.6, 124.5, 120.1, 119.6, 119.5, 117.5, 117.4; HRMS (ESI): $m / z$ cald for $\mathrm{C}_{14} \mathrm{H}_{13} \mathrm{NO}_{4}[\mathrm{M}-\mathrm{H}]^{-\cdot} 306.0772$ found 306.0775 .

(4-(2-Hydroxybenzoyl)-1H-pyrrol-2-yl)(4-nitrophenyl) methanone (4l). As a yellow solid, yield $50 \%, \mathrm{mp} 210-212{ }^{\circ} \mathrm{C} ;{ }^{1} \mathrm{H} \mathrm{NMR}$ $\left(500 \mathrm{MHz}\right.$, DMSO $\left.\mathrm{d}_{6}\right): \delta 12.93(\mathrm{~s}, 1 \mathrm{H}), 10.89(\mathrm{~s}, 1 \mathrm{H}), 8.37$ (d, $J=$ $8.1 \mathrm{~Hz}, 2 \mathrm{H}), 8.07$ (d, $J=8.1 \mathrm{~Hz}, 2 \mathrm{H}), 7.77$ (s, 1H), 7.59 (d, $J=$ $7.4 \mathrm{~Hz}, 1 \mathrm{H}), 7.43(\mathrm{t}, J=7.6 \mathrm{~Hz}, 1 \mathrm{H}), 7.15(\mathrm{~s}, 1 \mathrm{H}), 6.95(\mathrm{dd}, J=$ 19.5, 7.8 Hz, 2H); ${ }^{13} \mathrm{C}$ NMR (125 MHz, DMSO-d $\left.{ }_{6}\right): \delta 191.7,183.4$, $158.3,149.8,143.3,134.1,132.6,131.4,130.8,130.4,126.0$, 124.4, 124.3, 120.7, 119.6, 117.5; HRMS (ESI): $\mathrm{m} / \mathrm{z}$ cald for $\mathrm{C}_{18} \mathrm{H}_{12} \mathrm{~N}_{2} \mathrm{O}_{5}[\mathrm{M}-\mathrm{H}]^{-\cdot} 335.0673$ found 335.0676.

(4-(2-Hydroxybenzoyl)-1H-pyrrol-2-yl)(3-nitrophenyl) methanone (4m). As a light yellow solid, yield 52\%, mp 205$207{ }^{\circ} \mathrm{C} ;{ }^{1} \mathrm{H}$ NMR (500 MHz, DMSO-d $\left.)_{6}\right): \delta 12.98$ (s, 1H), 10.91 (s, $1 \mathrm{H}), 8.54(\mathrm{~d}, J=36.2 \mathrm{~Hz}, 2 \mathrm{H}), 8.32(\mathrm{~s}, 1 \mathrm{H}), 7.83(\mathrm{~d}, J=49.5 \mathrm{~Hz}$, 2H), $7.64(\mathrm{~s}, 1 \mathrm{H}), 7.46(\mathrm{~s}, 1 \mathrm{H}), 7.27(\mathrm{~s}, 1 \mathrm{H}), 6.98(\mathrm{~s}, 1 \mathrm{H}) ;{ }^{13} \mathrm{C}$ NMR (125 MHz, DMSO-d ${ }_{6}$ ): $\delta$ 191.7, 158.5 148.3, 135.3, 134.2, 132.5, 131.3, 131.0, 127.1, 126.0, 123.8, 120.5, 119.6, 117.6; HRMS (ESI): $m / z$ cald for $\mathrm{C}_{18} \mathrm{H}_{12} \mathrm{~N}_{2} \mathrm{O}_{5}[\mathrm{M}-\mathrm{H}]^{-\cdot} 335.0673$ found 335.0676 .

(5-Benzoyl-1H-pyrrol-3-yl)(2-hydroxy-5-methylphenyl) methanone (5a). As a pale yellow solid, yield 84\%, mp 146$148{ }^{\circ} \mathrm{C} ;{ }^{1} \mathrm{H}$ NMR $\left(500 \mathrm{MHz}, \mathrm{CDCl}_{3}\right): \delta 11.73(\mathrm{~s}, 1 \mathrm{H}), 10.02(\mathrm{~s}, 1 \mathrm{H})$, $7.98-7.94(\mathrm{~m}, 2 \mathrm{H}), 7.72(\mathrm{dd}, J=3.1,1.3 \mathrm{~Hz}, 1 \mathrm{H}), 7.67-7.61(\mathrm{~m}$, 2H), 7.56-7.51 (m, 2H), 7.38 (dd, $J=2.3,1.3 \mathrm{~Hz}, 1 \mathrm{H}), 7.31$ (dd, $J$ $=8.4,1.9 \mathrm{~Hz}, 1 \mathrm{H}), 6.97(\mathrm{~d}, J=8.4 \mathrm{~Hz}, 1 \mathrm{H}), 2.32(\mathrm{~s}, 3 \mathrm{H}) ;{ }^{13} \mathrm{C} \mathrm{NMR}$ $\left(125 \mathrm{MHz} \mathrm{CDCl}_{3}\right): \delta 193.5,185.0,160.4,137.2,136.7,132.2$, $131.6,131.3,129.0,128.9,128.6,127.9,125.6,119.8,119.5$, 118.2, 20.6; HRMS (ESI): $m / z$ cald for $\mathrm{C}_{19} \mathrm{H}_{15} \mathrm{NO}_{3}[\mathrm{M}-\mathrm{H}]^{-}$. 304.0979 found 304.0984 .

(4-(2-Hydroxy-5-methylbenzoyl)-1H-pyrrol-2-yl)(4-

methoxyphenyl) methanone (5b). As a light yellow solid, yield 81\%, mp 132-135 ${ }^{\circ} \mathrm{C} ;{ }^{1} \mathrm{H}$ NMR (500 MHz, $\left.\mathrm{CDCl}_{3}\right): \delta 11.75(\mathrm{~s}, 1 \mathrm{H})$, 10.25 (s, 1H), 8.04-7.96 (m, 2H), $7.70(\mathrm{dd}, J=3.1,1.3 \mathrm{~Hz}, 1 \mathrm{H})$, $7.66(\mathrm{~d}, J=1.6 \mathrm{~Hz}, 1 \mathrm{H}), 7.37$ (dd, $J=2.3,1.3 \mathrm{~Hz}, 1 \mathrm{H}), 7.31$ (dd, $J$ $=8.4,2.0 \mathrm{~Hz}, 1 \mathrm{H}), 7.03-7.00(\mathrm{~m}, 2 \mathrm{H}), 6.97(\mathrm{~d}, J=8.4 \mathrm{~Hz}, 1 \mathrm{H})$, $3.91(\mathrm{~d}, J=4.7 \mathrm{~Hz}, 3 \mathrm{H}), 2.32$ (s, 3H); ${ }^{13} \mathrm{C} \mathrm{NMR}\left(125 \mathrm{MHz}, \mathrm{CDCl}_{3}\right)$ : $\delta 193.6,183.7,163.5,160.4,136.6,131.7,131.4,131.3,129.8$, 128.6, 127.9, 125.5, 119.9, 118.7, 118.2, 113.9, 55.5, 20.6; HRMS (ESI): $m / z$ cald for $\mathrm{C}_{20} \mathrm{H}_{17} \mathrm{NO}_{4}[\mathrm{M}-\mathrm{H}]^{-\cdot} 334.1085$ found 334.1087.

\section{(4-(2-Hydroxy-5-methylbenzoyl)-1H-pyrrol-2-yl)(p-tolyl)} methanone (5c). As a pale brown solid, yield 75\%, mp 198$200{ }^{\circ} \mathrm{C} ;{ }^{1} \mathrm{H}$ NMR $\left(500 \mathrm{MHz}, \mathrm{CDCl}_{3}\right): \delta 11.75(\mathrm{~s}, 1 \mathrm{H}), 10.26(\mathrm{~s}, 1 \mathrm{H})$, $7.88(\mathrm{~d}, J=8.1 \mathrm{~Hz}, 2 \mathrm{H}), 7.71(\mathrm{dd}, J=3.2,1.3 \mathrm{~Hz}, 1 \mathrm{H}), 7.65(\mathrm{~d}, J=$ $1.6 \mathrm{~Hz}, 1 \mathrm{H}), 7.37$ (dd, $J=2.4,1.4 \mathrm{~Hz}, 1 \mathrm{H}), 7.31$ (dd, $J=12.1$, 
$5.2 \mathrm{~Hz}, 3 \mathrm{H}), 6.97(\mathrm{~d}, J=8.4 \mathrm{~Hz}, 1 \mathrm{H}), 2.46(\mathrm{~s}, 3 \mathrm{H}), 2.32(\mathrm{~s}, 3 \mathrm{H}) ;{ }^{13} \mathrm{C}$ NMR (125 MHz, $\mathrm{CDCl}_{3}$ ): $\delta$ 193.6, 185.0, 160.4, 143.6, 136.6, $134.6,131.7,131.4,129.4,129.3$, 129.2, 129.0, 128.0, 125.5, 120.0, 119.3, 118.2, 21.6, 20.6; HRMS (ESI): $\mathrm{m} / \mathrm{z}$ cald for $\mathrm{C}_{20} \mathrm{H}_{17} \mathrm{NO}_{3}[\mathrm{M}-\mathrm{H}]^{-\cdot} 318.1136$ found 318.1140.

(5-([1,1'-Biphenyl]-4-carbonyl)-1H-pyrrol-3-yl)(2-hydroxy-5methylphenyl)methanone (5d). As a pale yellow solid, yield $74 \%$, mp $143-145{ }^{\circ} \mathrm{C} ;{ }^{1} \mathrm{H}$ NMR $\left(500 \mathrm{MHz}, \mathrm{CDCl}_{3}\right): \delta 11.74(\mathrm{~s}, 1 \mathrm{H})$, $10.00(\mathrm{~s}, 1 \mathrm{H}), 8.07-8.04(\mathrm{~m}, 2 \mathrm{H}), 7.79-7.74(\mathrm{~m}, 2 \mathrm{H}), 7.73(\mathrm{dd}, J=$ $3.1,1.3 \mathrm{~Hz}, 1 \mathrm{H}), 7.67(\mathrm{dt}, J=8.4,4.2 \mathrm{~Hz}, 3 \mathrm{H}), 7.52-7.47(\mathrm{~m}, 2 \mathrm{H})$, $7.44-7.40(\mathrm{~m}, 2 \mathrm{H}), 7.32$ (dd, $J=8.5,2.0 \mathrm{~Hz}, 1 \mathrm{H}), 6.97$ (d, $J=$ $8.4 \mathrm{~Hz}, 1 \mathrm{H}), 2.33$ (s, 3H); ${ }^{13} \mathrm{C}$ NMR (125 MHz, DMSO-d 6 ): $\delta 191.9$, $184.4,156.0,144.4,139.4,136.8,134.7,131.0,131.7,130.6$, $129.9,129.6,129.6,128.8,128.3$, 127.4, 127.4, 127.3, 125.8, 124.3, 119.6, 117.4, 40.3, 40.3, 40.2, 40.1, 40.0, 39.9, 39.7, 39.6, 39.4, 39.2, 20.4; HRMS (ESI): $m / z$ cald for $\mathrm{C}_{25} \mathrm{H}_{19} \mathrm{NO}_{3}[\mathrm{M}-\mathrm{H}]^{-\cdot}$ 380.1292 found 380.1294 .

(5-(4-Fluorobenzoyl)-1H-pyrrol-3-yl)(2-hydroxy-5-

methylphenyl)methanone (5e). As a pale brown solid, yield 69\%, mp 110-112 ${ }^{\circ} \mathrm{C} ;{ }^{1} \mathrm{H}$ NMR (500 MHz, DMSO-d 6 ): $\delta 12.79(\mathrm{~s}$, $1 \mathrm{H}), 10.66$ (s, 1H), 7.97 (dd, $J=8.5,5.6 \mathrm{~Hz}, 2 \mathrm{H}), 7.73$ (d, $J=$ $1.7 \mathrm{~Hz}, 1 \mathrm{H}), 7.40(\mathrm{dd}, J=9.8,7.7 \mathrm{~Hz}, 3 \mathrm{H}), 7.26(\mathrm{~d}, J=8.4 \mathrm{~Hz}$, 1H), 7.14 (s, 1H), 6.88 (d, $J=8.3 \mathrm{~Hz}, 1 \mathrm{H}), 2.27$ (s, 3H); ${ }^{13} \mathrm{C}$ NMR (125 MHz, DMSO-d ${ }_{6}$ ): $\delta$ 191.8, 183.5, 156.4, 134.8, 132.0, 131.9, $131.7,131.6,130.8,128.2,125.8,124.2,119.7,117.4,116.3$, 116.1, 20.5; HRMS (ESI): $m / z$ cald for $\mathrm{C}_{19} \mathrm{H}_{14} \mathrm{FNO}_{3}[\mathrm{M}-\mathrm{H}]^{-}$. 322.0885 found 323.0888 .

(5-(4-Chlorobenzoyl)-1H-pyrrol-3-yl)(2-hydroxy-5-

methylphenyl) methanone (5f). As a pale brown solid, yield 65\%, mp 201-204 ${ }^{\circ} \mathrm{C} ;{ }^{1} \mathrm{H}$ NMR (500 MHz, $\left.\mathrm{CDCl}_{3}\right): \delta 11.71(\mathrm{~s}, 1 \mathrm{H})$, 10.12 (s, 1H), 7.93-7.90 (m, 2H), 7.73 (dd, $J=3.1,1.3 \mathrm{~Hz}, 1 \mathrm{H})$, $7.63(\mathrm{~d}, J=1.6 \mathrm{~Hz}, 1 \mathrm{H}), 7.53-7.49(\mathrm{~m}, 2 \mathrm{H}), 7.35(\mathrm{dd}, J=2.3$, $1.3 \mathrm{~Hz}, 1 \mathrm{H}$ ), 7.32 (dd, $J=8.5,1.9 \mathrm{~Hz}, 1 \mathrm{H}), 6.97$ (d, $J=8.4 \mathrm{~Hz}$, $1 \mathrm{H}), 2.30$ (d, $J=19.1 \mathrm{~Hz}, 3 \mathrm{H}) ;{ }^{13} \mathrm{C}$ NMR (125 $\mathrm{MHz}, \mathrm{CDCl}_{3}$ ): $\delta 193.4,183.8,160.4,139.1,136.7,135.7,135.4,131.4,131.3$, $130.6,130.4,129.5,129.1,128.9,127.9,125.6,125.5,119.8$, 119.6, 118.2 , 117.9, 102.6, 40.0, 29.6, 20.8; HRMS (ESI): $\mathrm{m} / z$ cald. for $\mathrm{C}_{19} \mathrm{H}_{14} \mathrm{ClNO}_{3}[\mathrm{M}-\mathrm{H}]^{-\cdot} 338.0589$ found 338.0594.

(5-(4-Bromobenzoyl)-1H-pyrrol-3-yl)(2-hydroxy-5-

methylphenyl) methanone (5g). As a pale yellow solid, yield $68 \%, \mathrm{mp} 184-187^{\circ} \mathrm{C} ;{ }^{1} \mathrm{H} \mathrm{NMR}\left(500 \mathrm{MHz}, \mathrm{CDCl}_{3}\right): \delta 11.70(\mathrm{~s}, 1 \mathrm{H})$, $9.99(\mathrm{~s}, 1 \mathrm{H}), 7.85-7.82(\mathrm{~m}, 2 \mathrm{H}), 7.73-7.70(\mathrm{~m}, 1 \mathrm{H}), 7.69-7.66(\mathrm{~m}$, $2 \mathrm{H}), 7.63(\mathrm{~d}, J=1.6 \mathrm{~Hz}, 1 \mathrm{H}), 7.34(\mathrm{dt}, J=3.5,1.8 \mathrm{~Hz}, 1 \mathrm{H}), 7.32$ (dd, $J=8.5,2.0 \mathrm{~Hz}, 1 \mathrm{H}), 6.97(\mathrm{~d}, J=8.4 \mathrm{~Hz}, 1 \mathrm{H}), 2.32(\mathrm{~s}, 3 \mathrm{H}) ;{ }^{13} \mathrm{C}$ NMR (125 MHz, $\left.\mathrm{CDCl}_{3}\right): \delta 160.5,136.8,132.0,131.9,131.2$, 130.5, 129.1, 127.9, 125.8, 119.4, 118.2, 20.3; HRMS (ESI): $\mathrm{m} / \mathrm{z}$ cald for $\mathrm{C}_{19} \mathrm{H}_{14} \mathrm{BrNO}_{3}[\mathrm{M}-\mathrm{H}]^{-\cdot} 382.0084$ found 382.0084 .

4-(4-(2-Hydroxy-5-methylbenzoyl)-1H-pyrrole-2-carbonyl) benzonitrile $(5 \mathbf{h})$. As a yellow solid, yield $62 \%, \mathrm{mp} 198-203{ }^{\circ} \mathrm{C}$; ${ }^{1} \mathrm{H}$ NMR (400 MHz, $\left.\mathrm{CDCl}_{3}\right): \delta 11.68(\mathrm{~s}, 1 \mathrm{H}), 10.31(\mathrm{~s}, 1 \mathrm{H}), 8.03(\mathrm{~d}$, $J=8.4 \mathrm{~Hz}, 2 \mathrm{H}), 7.84(\mathrm{~d}, J=8.4 \mathrm{~Hz}, 2 \mathrm{H}), 7.77(\mathrm{dd}, J=3.2,1.2 \mathrm{~Hz}$, $1 \mathrm{H}), 7.61$ (d, $J=1.4 \mathrm{~Hz}, 1 \mathrm{H}), 7.33(\mathrm{dd}, J=8.5,1.6 \mathrm{~Hz}, 2 \mathrm{H}), 6.97$ (d, $J=8.5 \mathrm{~Hz}, 1 \mathrm{H}), 2.32(\mathrm{~s}, 3 \mathrm{H}) ;{ }^{13} \mathrm{C} \mathrm{NMR}\left(125 \mathrm{MHz}, \mathrm{CDCl}_{3}\right)$ : $\delta 193.3,183.4,160.5,140.8,137.0,132.5,131.2,131.0,130.0$, 129.5, 128.0, 126.0, 120.3 , 119.7, 118.4, 117.9, 116.1, 20.6; HRMS (ESI): $m / z$ cald. for $\mathrm{C}_{20} \mathrm{H}_{14} \mathrm{~N}_{2} \mathrm{O}_{3}[\mathrm{M}-\mathrm{H}]^{-\cdot} 329.0932$ found 329.0935 .
Ethyl

4-(2-hydroxy-5-methylbenzoyl)-1H-pyrrole-2carboxylate (5n). As a light yellow solid, yield 23\%, mp 146$148{ }^{\circ} \mathrm{C} ;{ }^{1} \mathrm{H}$ NMR $\left(500 \mathrm{MHz}, \mathrm{DMSO}^{-\mathrm{d}_{6}}\right): \delta 12.64(\mathrm{~s}, 1 \mathrm{H}), 10.67(\mathrm{~d}, J$ $=19.6 \mathrm{~Hz}, 1 \mathrm{H}), 7.57(\mathrm{dd}, J=3.3,1.6 \mathrm{~Hz}, 1 \mathrm{H}), 7.37(\mathrm{t}, J=10.0 \mathrm{~Hz}$, $1 \mathrm{H}), 7.25(\mathrm{dd}, J=8.4,2.0 \mathrm{~Hz}, 1 \mathrm{H}), 7.15-7.08(\mathrm{~m}, 1 \mathrm{H}), 6.89(\mathrm{t}, J=$ $14.1 \mathrm{~Hz}, 1 \mathrm{H}), 4.28(\mathrm{q}, J=7.1 \mathrm{~Hz}, 2 \mathrm{H}), 2.27(\mathrm{~s}, 3 \mathrm{H}), 1.30(\mathrm{t}, J=$ $7.1 \mathrm{~Hz}, 3 \mathrm{H}) ;{ }^{13} \mathrm{C}$ NMR (125 MHz, DMSO-d 6 ): $\delta$ 191.9, 160.5, 156.4 , 134.6, 130.6, 129.8, 128.1, 125.3, 125.0, 124.2, 124.1, 119.2, 117.4, 116.2, 60.7, 20.5, 14.8; HRMS (ESI): $\mathrm{m} / \mathrm{z}$ cald for $\mathrm{C}_{25} \mathrm{H}_{19} \mathrm{NO}_{3}[\mathrm{M}-\mathrm{H}]^{-\cdot} 380.1292$ found 380.1294 .

\section{Conflicts of interest}

There are no conflicts to declare.

\section{Acknowledgements}

We are thankful to the Department of Pharmaceuticals (DoP), the Ministry of Chemicals and Fertilizers Govt of India, New Delhi for the award of NIPER Fellowship.

\section{References}

1 (a) V. Estevez, M. Villacampa and J. C. Menendez, Chem. Soc. Rev., 2010, 39, 4402; (b) V. Estevez, M. Villacampa and J. C. Menendez, Chem. Soc. Rev., 2014, 43, 4633; (c) H. Fan, J. Peng, M. T. Hamann and J. F. Hu, Chem. Rev., 2008, 108, 264; (d) A. Hall, S. Atkinson, S. H. Brown, I. P. Chessell, A. Chowdhury, G. M. P. Giblin, P. Goldsmith, M. P. Healy, K. S. Jandu, M. R. Johnson, A. D. Michel, A. Naylor and J. A. Sweeting, Bioorg. Med. Chem. Lett., 2007, 17, 1200; (e) C. V. Galliford and K. A. Scheidt, Angew. Chem., Int. Ed., 2007, 46, 8748.

2 (a) J. Lehuede, B. Fauconneau, L. Barrier, M. Ourakow, A. Piriou and J. M. Vierfond, Eur. J. Med. Chem., 1999, 34, 991; (b) A. Furstner, Angew. Chem., 2003, 115, 3706; Angew. Chem., Int. Ed., 2003, 42, 3582.

3 (a) L. M. D. Coen, T. S. A. Heugebaert, D. Garcia and C. V. Stevens, Chem. Rev., 2016, 116, 80; (b) J. W. Blunt, B. R. Copp, R. A. Keyzers, M. H. G. Munroa and M. R. Prinsep, Nat. Prod. Rep., 2014, 31, 160; (c) M. S. Mohamed and S. S. Fathallah, Mini-Rev. Org. Chem., 2014, 11, 477; (d) S. S. Gholap, Eur. J. Med. Chem., 2016, 110, 13; (e) M. Takase, T. Narita, W. Fujita, M. S. Asano, T. Nishinaga, H. Benten, K. Yoza and K. Mullen, J. Am. Chem. Soc., 2013, 135, 8031; (f) D. Imbri, J. Tauber and T. Opatz, Mar. Drugs, 2014, 12, 6142.

4 (a) R. E. Nizurski-Mann and M. P. Cava, Heterocycles, 1992, 34, 2003; (b) C. D'Silva and D. A. Walker, J. Org. Chem., 1998, 63, 6715.

5 (a) T. P. Toube, B. A. Trofimov, G. Cirrincione, A. M. Almerico, E. Aiello, G. Dattolo, H. McNab and L. C. Monahan, in Chemistry of Heterocyclic Compounds: Pyrroles, Part II, The Synthesis, Reactivity and Physical Properties of Substituted Pyrroles, ed. R. A. Jones, John Wiley \& Sons Inc., New York, 2008, vol. 48, p. 1; (b) E. T. Pelkey, 
in Progress in Heterocyclic Chemistry, ed. G. W. Gribble and J. A. Joule, Elsevier, S. A., 2005, vol. 17, p. 109.

6 (a) J. T. Gupton, Top. Heterocycl. Chem., 2006, 2, 53; (b) N. Amishiro, S. Nagamura, E. Kobayashi, A. Okamoto, K. Gomi and H. Saito, Chem. Pharm. Bull., 1999, 47, 1393; (c) N. Amishiro, S. Nagamura, E. Kobayashi, A. Okamoto, K. Gomi, M. Okabe and H. Saito, Bioorg. Med. Chem., 2000, 8, 1637.

7 R. W. Burli, D. McMinn, J. A. Kaizerman, W. Hu, Y. Ge, Q. Pack, V. Jiang, M. Gross, M. Garcia, R. Tanaka and H. E. Moser, Bioorg. Med. Chem. Lett., 2004, 14, 1253.

8 (a) H. M. Meshram, B. R. V. Prasad and D. A. Kumar, Tetrahedron Lett., 2010, 51, 3477; (b) M. Del Poeta, W. A. Schell, C. C. Dykstra, S. Jones, R. R. Tidwell, A. Czarny, M. Bajic, A. Kumar, D. Boykin and J. R. Perfect, Antimicrob. Agents Chemother., 1998, 42, 2495; (c) M. Z. Wang, H. Xu, T. W. Liu, Q. Feng, S. J. Yu, S.-H. Wang and Z. M. Li, Eur. J. Med. Chem., 2011, 46, 1463.

9 F. A. Davis, K. Bowen, H. Xu and V. Velvadapu, Tetrahedron, 2008, 64, 4174.

10 G. La Regina, R. Bai, A. Coluccia, V. Famiglini, S. Pelliccia, S. Passacantilli, C. Mazzoccoli, V. Ruggieri, L. Sisinni, A. Bolognesi, W. M. Rensen, A. Miele, M. Nalli, R. Alfonsi, L. Di Marcotullio, A. Gulino, A. Brancale, E. Novellino, G. Dondio, S. Vultaggio, M. Varasi, C. Mercurio, E. Hamel, P. Lavia and R. Silvestri, J. Med. Chem., 2014, 57, 6531.

11 (a) M. Menichincheri, C. Albanese, C. Alli, D. Ballinari, A. Bargiotti, M. Caldarelli, A. Ciavolella, A. Cirla, M. Colombo, F. Colotta, V. Croci, R. D'Alessio, M. D'Anello, A. Ermoli, F. Fiorentini, B. Forte, A. Galvani, P. Giordano, A. Isacchi, K. Martina, A. Molinari, J. K. Moll, A. Montagnoli, P. Orsini, F. Orzi, E. Pesenti, A. Pillan, F. Roletto, A. Scolaro, M. Tato, M. Tibolla, B. Valsasina, M. Varasi, P. Vianello, D. Volpi, C. Santocanale and E. Vanotti, J. Med. Chem., 2010, 53, 7296; (b) D. M. Bailey, R. E. Johnson and U. J. Salvador, J. Med. Chem., 1973, 16, 1298.

12 (a) L. Knorr, Ber. Dtsch. Chem. Ges., 1884, 17, 1635; (b) C. Paal, Ber. Dtsch. Chem. Ges., 1885, 18, 367; (c) H. S. P. Rao, S. Jothilingam and H. W. Scheeren, Tetrahedron, 2004, 60, 1625; (d) G. Minetto, L. F. Raveglia, A. Sega and M. Taddei, Eur. J. Org. Chem., 2005, 2005, 5277. 13 A. Hantzsch, Ber. Dtsch. Chem. Ges., 1890, 23, 1474.

14 (a) N. C. Misra, K. Panda, H. Ila and H. Junjappa, J. Org. Chem., 2007, 72, 1246; (b) J. L. Bullington, R. R. Wolff and P. F. Jackson, J. Org. Chem., 2002, 67, 9439; (c) D. H. R. Barton, J. Kervagoret and S. Z. Zard, Tetrahedron, 1990, 46, 7587.
15 C. K. Ghosh, J. Heterocycl. Chem., 1983, 20, 1437.

16 G. Sabitha, Aldrichimica Acta, 1996, 29, 15.

17 C. K. Ghosh, Indian J. Chem., Sect. B: Org. Chem. Incl. Med. Chem., 1997, 36, 968.

18 (a) C. K. Ghosh, Heterocycles, 2004, 63, 2875; (b) J. H. Boyer and F. C. Canter, Chem. Rev., 1954, 54, 1; (c) A. S. Plaskon, S. V. Ryabukhin, D. M. Volochnyuk, K. S. Gavrilenko, A. N. Shivanyuk and A. A. Tolmachev, J. Org. Chem., 2008, 73, 6010; (d) M. Lacova, A. Puchala, E. Solcanyova, J. Lac, P. Kois, J. Chovancova and D. Rasala, Molecules, 2005, 10, 809; (e) A. G. P. R. Figueiredo, A. C. Tome, A. M. S. Silva and J. A. S. Cavaleiro, Tetrahedron, 2007, 63, 910; $(f)$ L. M. Sanchez, A. G. Sathicq, J. L. Jios, G. T. Baronetti, H. J. Thomas and G. P. Romanelli, Tetrahedron Lett., 2011, 52, 4412.

19 (a) G. L'Abbe, Chem. Rev., 1969, 69, 345; (b) S. Nekkanti, V. Pooladanda, M. Veldandi, R. Tokala, C. Godugu and N. Shankaraiah, ChemistrySelect, 2017, 2, 7210.

20 T. Patonay, K. Konya and E. Juhasz-Toth, Chem. Soc. Rev., 2011, 40, 2797.

21 The Chemistry of the Azido Group, ed. S. Patai, WileyInterscience, London-New York-Sydney-Toronto, 1971.

22 G. L'Abbe and A. Hassner, Angew. Chem., Int. Ed. Engl., 1971, 10, 98.

23 G. L'Abbe, Angew. Chem., 1975, 87, 831.

24 Azides and Nitrenes; Reactivity and Utility, ed. E. V. F. Scriven, Academic Press, Orlando, 1984.

25 E. V. F. Scriven and K. Turnbull, Chem. Rev., 1988, 88, 297.

26 S. Brase, C. Gil, K. Knepper and V. Zimmermann, Angew. Chem., Int. Ed., 2005, 44, 5188; K. Banert, Liebigs Ann./Recl., 1997, 2005.

27 S. Kamijo, C. Kanazawa and Y. Yamamoto, J. Am. Chem. Soc., 2005, 127, 9260.

28 J. Y. Liao, W. J. Yap, J. E. Wu, M. W. Wong and Y. Zhao, Chem. Commun., 2017, 53, 9067.

29 X. Qi, H. Xiang, Y. Yang and C. Yang, RSC Adv., 2015, 5, 98549.

30 M. Sathish, J. Chetna, N. H. Krishna, N. Shankaraiah, A. Alarifi and A. Kamal, J. Org. Chem., 2016, 81, 2159.

31 (a) Y. Arikawa, H. Nishida, O. Kurasawa, A. Hasuoka, K. Hirase, N. Inatomi, Y. Hori, J. Matsukawa, A. Imanishi, M. Kondo, N. Tarui, T. Hamada, T. Takagi, T. Takeuchi and M. Kajino, J. Med. Chem., 2012, 55, 4446; (b) B. D. Roth, Prog. Med. Chem., 2002, 40, 1.

32 (a) Z. Lao and P. H. Toy, Beilstein J. Org. Chem., 2016, 12, 2577; (b) H. B. Tukhtaev, K. L. Ivanov, S. I. Bezzubov, D. A. Cheshkov, M. Y. Melnikov and E. M. Budynina, Org. Lett., 2019, 21, 1087. 